talenta

\title{
CORRELATION BETWEEN NUCLEUS FACTOR KAPPA B AND MICROVESSEL DENSITY IN NASOPHARYNGEAL CARCINOMA
}

\section{Farrel, Izry Naomi Tobing", Farhat, Rizalina A. Asnir, Adlin Adnan}

University of Sumatera Utara, Faculty of Medicine, Central General Hospital of Haji Adam Malik, Departement of Otorhinolaryngology, Head and Neck Surgery, Medan, Indonesia

\section{Abstract}

Introduction: Nasopharyngeal carcinoma (NPC) is an aggressive head and neck cancer, mostly associated with EBV infection. Nuclear factor kappa $\mathrm{B}(\mathrm{NF}-\kappa \mathrm{B})$ is transcription factors that act as a tumor promoter, especially in inflammation-associated cancer. It also attracts angiogenesis. Microvessel Density (MVD) is widely used as an index for tumor angiogenesis. There have been no studies found about the correlation of NF- $\mathrm{KB}$ and MVD expression in NPC.

Objective: The aim of this study is to investigate the correlation of NF- $\mathrm{kB}$ and MVD expression that may affect targeted therapies in NPC patients

Methods: A total of 30 paraffin blocks of NPC patients biopsies were assessed immunohistochemically for NF$\kappa \mathrm{B}$ expression and MVD. Data were analyzed using the Spearman's nonparametric test to assess the correlation between NF- $\kappa$ B expression and MVD.

Results: Positive NF- $\mathrm{KB}$ expression was found in $22(73.33 \%)$ patients and negative in $8(26.67 \%)$ patients. High MVD expression in 17 (56.67\%) patients and low MVD expression in 13 (43.33\%) patients. There was no significant correlation found between NF- $\mathrm{KB}$ and MVD.

Conclusion: This study has not confirmed any correlation between NF- $\mathrm{kB}$ and MVD. Further research needs to be done to get a better assessment on nuclear proliferation rates and tumor-related angiogenesis in NPC.
\end{abstract}

\section{Article Info}

Keywords: Nuclear Factor Kappa B, microvessel density, nasopharyngeal carcinoma

\section{*Corresponding author: \\ Address: J1. Dr. Mansyur No.5, Padang Bulan, Kec. Medan Baru, Kota Medan, Sumatera Utara 20155}

e-mail: izrynaomi@gmail.com

\section{INTRODUCTION}

Nasopharyngeal carcinoma (NPC) is an aggressive head and neck cancer frequently found especially in endemic regions such as Southeast Asia. Etiological factors of NPC consist of genetic, environmental, and viral factors. Epstein-Barr virus (EBV) infection is considered to play an important role as around $90 \%$ of the adult population throughout the world is EBV-positive [1, 2].

Almost $98 \%$ of NPC are associated with EBV infection. Nonkeratinizing is more consistently associated with EBV compared to keratinizing NPC. The EBV encoded latent membrane proteins (LMP1) activate multiple signaling pathways including $\mathrm{NF}-\kappa \mathrm{B}$, and stimulate the growth of NPC by up-regulating growth factor receptors and suppressing cell cycle regulators [2].

Nuclear factor kappa B $(\mathrm{NF}-\kappa \mathrm{B})$ is transcription factors in the cell cytoplasm and when activated it will translocate into the nucleus. Its activation is induced by various types of agents such as stress, cigarette smoke, viruses, bacteria, inflammatory stimuli, cytokines, free radicals, carcinogens, tumor promoters and endotoxins. NF- $\kappa \mathrm{B}$ and the signaling pathways that activate them coordinate the innate and adaptive immune centers. NF- $\kappa \mathrm{B}$ works by inhibiting apoptosis (programmed cell death), increases cell proliferation and the inflammatory and immune response. Recently, misregulated NF- $\kappa \mathrm{B}$ activity has been known to have an important role in cancer development and progression [3, 4].

$\mathrm{NF}-\kappa \mathrm{B}$ has five different family members, they are: NF- $\kappa \mathrm{B} 1$ (p50/p105), NF-кB2 (p52/p100), RelA (p65), RelB and c-Rel. Before translocated into the nucleus, $N F-\kappa B 1$ and $N F-\kappa B 2$ are cleaved to the active p50 and p52 subunits, respectively. Two different NF- $\mathrm{B}$ activational pathways have been identified, a classical (canonical) pathway and an alternative (non-canonical) pathway [3-6].

$\mathrm{NF}-\kappa \mathrm{B}$ canonical pathway is mediated by an NF- $\kappa \mathrm{B}$ essential modulator (NEMO)-dependent inhibitory kappa B kinases (IKK), while the noncanonical pathway does not require NEMO [3, 4]. Pathogens and inflammatory signals activating NEMO/IKK will activate the canonical pathway. This activation will result in degradation of $\mathrm{I} \kappa \mathrm{B} \alpha / \mathrm{I} \kappa \mathrm{B} \beta / \mathrm{I} \kappa \mathrm{B} \varepsilon$ and nuclear translocation of RelA: p50, RelA:RelA and cRel:p50 dimer. Genes responsible for inflammation and survival will then be activated. Noncanonical pathway, however, will be activated through developmental signals activating NIK/IKK1. IkB $\delta$ will be degradated and $\mathrm{p} 100$ will be processed and nuclear translocation of Rel A:p50, RelB: p50 and RelB:p52 dimers will take place, eventually it will activates the genes responsible for organ development [4]. By knowing the significance and specific pathways involved in activation, the opportunity to find targeted therapies to prevent the development of NPCs at an early stage will be widely open.

$\mathrm{NF}-\kappa \mathrm{B}$ can play 2 opposing roles in tumorigenesis. First, it acts as an inducer for the immune cells to express inflammatory cytokines, which then enhance tumor cell survival and angiogenesis. Second, it also promotes apoptosis via death receptors and Fas/CD95 and thereby delays tumor progression [7]

Neoangiogenesis plays an important role in tumor growth and metastasis formation. It provides adequate oxygenation and nourishment for the tumor. This process of neovascularization depends on the ability to release specific factors that stimulate and inhibit new blood vessel formation [8]. Angiogenic vessels can be visualized with immunohistochemical staining, either using monoclonal antibody or endothelial cell antigens [9]. Assessing microvessel density (MVD) is a way to evaluate the role of neoangiogenesis in the tumor progression. The aim of this study is to investigate the correlation of NF- $\mathrm{B}$ expression and MVD that may affect targeted therapies in NPC patients.

\section{MATERIAL AND METHODS}

\subsection{Case selection}

A total of 30 paraffin blocks were retrieved from biopsies of NPC patients who have never received treatment such as radiotherapy, chemotherapy or a combination of both. 


\subsection{Immunohistochemical staining}

The paraffin blocks were assessed for immunoreactivity of NF- $\kappa \mathrm{B}$ antibody. The level of NF-kB antibody intranuclear expression in tumor cells was evaluated by adding a score of intensity of staining and the score of area of staining (score of immunoreactivity). The intensity of staining identified under 40x magnification and categorized into four grades: 0 (background), $1+$ (weak), $2+$ (moderate), and $3+$ (strong). The area of staining was evaluated as follows: 0 , no staining of cells in any microscopic fields; score $1<25 \%, 2=25$ $50 \%, 3=>50 \%$ stained positive. The expression of NF- $\kappa \mathrm{B}$ was further assessed using two scales: low expression (score of immunoreactivity $=0-3$ ) and high expression (score of immunoreactivity $=4-6$ ).

The material from the same tissue is also examined immunohistochemically by using anti-Human Monoclonal Mouse CD31 Endothelial cell for calculating the micro blood vessel density. With a 40x magnification an area with the highest blood vessel is identified and named the 'hot spot' area. The vascular endothelial cell groups with or without lumen were calculated at 200x magnification. The measurement results are expressed in the total number of micro blood vessels (MV) per field of view. Total number of micro blood vessels $>45$ is considered high and $<45$ is considered low MVD. These evaluations were carried out by 3 pathologists without knowing the clinical data of the patients. The study was approved by the Health Research Ethical Committee of Universitas Sumatera Utara, Medan, Indonesia (No. 41/ KOMET/ FK USU/ 2015).

Data were analyzed using the Spearman's non parametric test and processed using SPSS 23 program to assess the correlation between NF- $\kappa B$ levels and MVD.

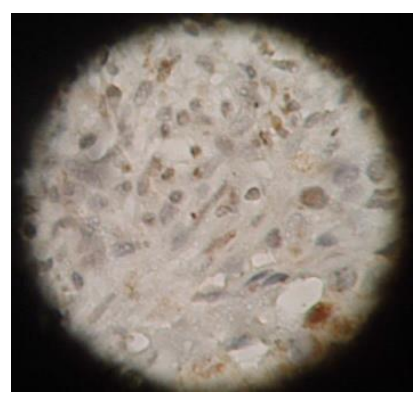

A

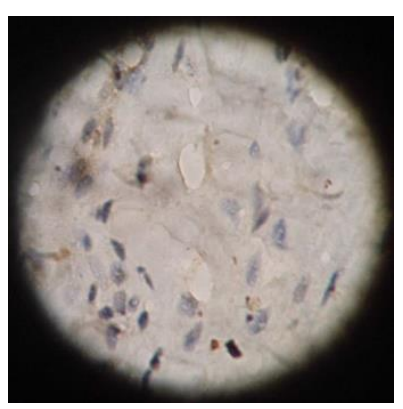

C

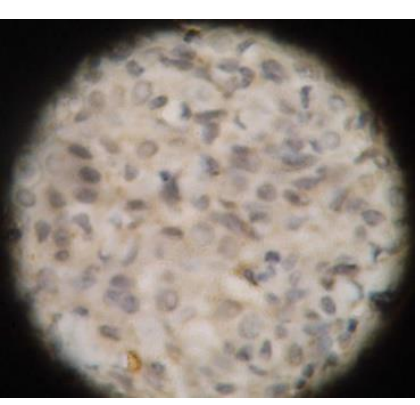

B

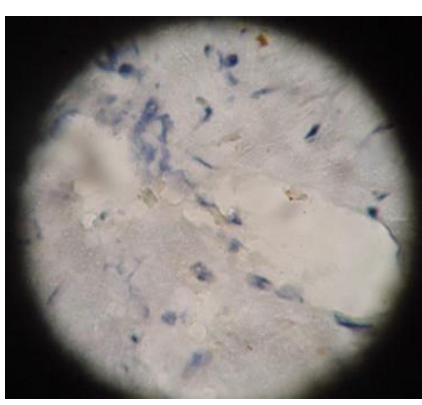

$\mathrm{D}$
Picture 1. A. NF- $\kappa B$ expression in placental control tissue with $40 \mathrm{x}$ magnification. B. NF- $\kappa B$ expression score +3 in NPC tissue with $40 x$ magnification. C. NF- $\kappa B$ expression score +2 in NPC tissue with $40 \mathrm{x}$ magnification. D. NF- $\kappa$ B expression score +1 in NPC tissue with $40 \mathrm{x}$ magnification

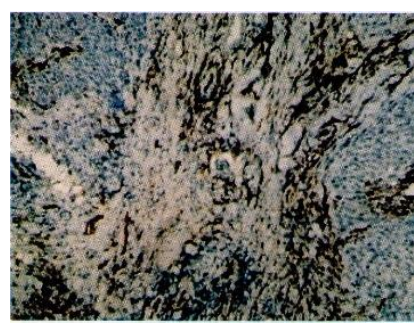

A

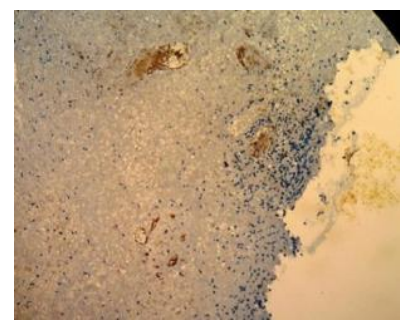

B
Picture 2. Expression of high MVD and low MVD (b) with 200x magnification

\section{RESULT}

A total of 30 NPC patients were analyzed. The clinicopathological characteristics of these patients were presented in table 1 .

Table 1. Patients' characteristics

\begin{tabular}{lrr}
\hline Characteristics & $\mathbf{n}$ & $\%$ \\
\hline Age (year) & 1 & 3.33 \\
$\leq 20$ & 6 & 20.0 \\
$21-40$ & 18 & 60.0 \\
$41-60$ & 5 & 16.67 \\
$>60$ & & \\
Gender & 21 & 70.00 \\
Male & 9 & 30.00 \\
Female & & \\
\hline Histopathology & 1 & 3.33 \\
Keratinizing squamous cell carcinoma & 16 & 53.34 \\
Non-keratinizing carcinoma & 13 & 43.33 \\
Undifferentiated carcinoma & & \\
\hline Tumor grade & 7 & 23.33 \\
T1 & 5 & 16.67 \\
T2 & 7 & 23.33 \\
T3 & 11 & 36.67 \\
T4 & & \\
Grade of metastatic lymph node & 1 & 3.33 \\
N0 & 8 & 26.67 \\
N1 & 8 & 26.67 \\
N2 & 13 & 43.33 \\
N3 & & \\
\hline Stage & 0 & 0.00 \\
I & 3 & 10.00 \\
II & 6 & 20.00 \\
III & 21 & 70.00 \\
IV & & \\
\hline
\end{tabular}

Most of the patients are in the age range of 41-60 years old. Male (70\%) are more common than female. Most common histopathology type was nonkeratinizing squamous cell carcinoma (53.34\%). Most of the patients were in advance stage, stage III and IV, $20 \%$ and $70 \%$ respectively.

Table 2. Frequency distribution of NF- $\kappa \mathrm{B}$ expression

\begin{tabular}{lcc}
\hline NF-אB Expression & $\mathbf{n}$ & $\boldsymbol{\%}$ \\
\hline High & 22 & 73.33 \\
Low & 8 & 26.67 \\
\hline Total & $\mathbf{3 0}$ & $\mathbf{1 0 0}$ \\
\hline
\end{tabular}

Based on immunohistochemical examination, positive NF- $\kappa$ B expression was found in $22(73.33 \%)$ patients and negative in $8(26.67 \%)$ patients.

Table 3. Frequency distribution of MVD expression

\begin{tabular}{llc}
\hline MVD Expression & $\mathbf{n}$ & $\boldsymbol{\%}$ \\
\hline High & 17 & 56.67 \\
Low & 13 & 43.33 \\
\hline Total & $\mathbf{3 0}$ & $\mathbf{1 0 0}$ \\
\hline
\end{tabular}

Immunohistochemical examination in nasopharyngeal carcinoma tissue showed high MVD expression in 17 (56.67\%) patients and low MVD expression in $13(43.33 \%)$ patients.

Table 4. Correlation of NF- $\kappa \mathrm{B}$ with MVD expression

\begin{tabular}{|c|c|c|c|}
\hline & & & MVD \\
\hline Spearman's rho & NF-kB & $\begin{array}{l}\text { Correlation coefficient } \\
\text { Sig. (2 tailed) } \\
\text { N }\end{array}$ & $\begin{array}{r}-.223 \\
.236 \\
30\end{array}$ \\
\hline
\end{tabular}

Table 4 showed no significant correlation was found between NF- $\mathrm{BB}$ and MVD).

\section{DISCUSSION}

NPC is a head and neck cancer that is frequently found in Indonesia. It is rated as the fourth most common tumor after cervical, breast, and skin cancer [10]. In Indonesia, the overall prevalence of NPC is estimated at $6.2 / 100,000$ or about 12,000 new cases per year [10]. And around $75-90 \%$ of NPC patients were classified as locally advanced stages (stage III and IV) at the point of diagnosis $[11,12]$.

According to Adham et al (2012) the undifferentiated type (WHO NPC type III) is the most frequent histopathologic type, and most closely 
associated with EBV infection. This EBV infection is affecting over $95 \%$ of the global adult population $[10,11]$.

In this study, most of the patients were diagnosed with non-keratinizing carcinoma (53.34\%) and stage III and stage IV, being the most frequent were 20 and $70 \%$, respectively. $\mathrm{Li}$ and Yong (2014) cited that nonkeratinizing carcinoma comprises over $95 \%$ of NPC in high incidence areas and approximately $75-87 \%$ in low incidence areas. These types of tumors are generally more radiosensitive compare to squamous cell carcinoma and have stronger relationships with EBV also [13].

In this study we found $22(73.33 \%)$ patients with positive $N F-\kappa B$ expression (table 2). This corresponds to the study of Rofi'ilet al (2013) in which they reported higher expression of NF- $\mathrm{BB}$ in NPC tissue compared to normal nasopharyngeal tissue [14]. Earlier studies have also shown distinct types of NF- $\kappa$ B complexes in EBV-positives NPC cells $[15,16]$. NPC is the best known inflammation-rich background cancer that is related to the virus-associated human cancers, EBV [17]. These findings support a crucial role of activated NF- $\kappa B$ signals especially in EBV-positive NPC. NF- $\kappa \mathrm{B}$ has been reported to have the ability to regulate several proteins that promote tumors growth, invasion, and metastasis, such as urokinase-type plasminogen activator and matrix metallopeptidase 9 (MMP-9). NF- $\mathrm{B}$ also has functioned as a tumor promoter in inflammation-associated cancer. NF- $\kappa \mathrm{B}$ activation and interactions with the microenvironment most likely play an important role not only in carcinogenesis but also in tumor invasion and metastasis [18].

Angiogenesis, or the formation of new blood vessels, is essential in tumor cell survival, which leads to tumor metastasis. Newly formed blood vessels provide increased oxygen and nutrients that are essential for the tumor to grow [19]. MVD is widely used as an index for tumor angiogenesis. Elevated MVD has been reported leads to a rapidly growing tumor with potential invasion, metastasis, and recurrence [17, 20].

We found high MVD expression in 17 (56.67\%) patients and low MVD expression in $13(43.33 \%)$ patients in the present study. Zhuo et al (2015) reported the status of MVD in NPC patients and they found higher MVD expressions in NPC patients with distant metastases (44.67 \pm 7.90$)$ compared to those without distant metastases $(42.90 \pm 8.38)$ [21]. In addition, Szafarowski et al (2018) showed that MVD expressions were found to be significantly elevated in the head and neck squamous cell carcinomas compared to the non-malignant control tissues $(\mathrm{p}=0.001)$ and to dysplastic tissues [22]. These studies revealed that immunohistochemical staining on microvessels density may provide valuable information about tumor progression and distant spread of NPC.

Correlation between NF- $\kappa$ B and MVD in NPC has not yet been established in previous studies. In the present study the analysis did not confirm any significant correlation between NF- $\mathrm{kB}$ and MVD in NPC. On the contrary, a study on adenoid cystic carcinoma of the salivary gland revealed a significant correlation between NF- $\kappa B$ and MVD [19].

There have been many studies measuring expression of $\mathrm{NF}-\mathrm{\kappa B}$ or MVD in cancer tissues, but with many variability in results and significance. Several different factors may affect these results. There were variations in study designs. Some studies counted 'hot spots' and some other used different cut off values to assess the expression of NF- $\mathrm{KB}[14,19,23,24]$. In this study we evaluated both the area percentage and immunostaining intensity score to be added up and obtain a total score of immunoreactivity as has been done in a recent research [25]. Similar concerns apply in the terms of methods for measuring microvascular density. Besides manual, MVD count can also be done by using computerized-image analysis systems [23]. But most studies have performed manual method as it is more suitable and available in almost all medical facility. For this reason, we chose to use manual method for counting MVD. Other concern may be the cut-off values selected in MVD analysis. There is no definite standard to determine MVD values. Some studies have used mean MVD value as cut-off points [21, 26], other derived arbitrary values from statistical analyses [22]. In this study MVD values were obtained between 0-122 microvessel per field of view with an average of $47+30,906$. Based on previous study, we referred MVD value as high if total microvessel $>45$ per field of view [27].

We are aware that our study didn't examined a homogenous group of NPC cases and included all subtypes of NPC and tumor stages. Therefore, these differences may be the reason why this particular study did not find any correlation between NF-kB and MVD. Further data collection is required to determine how exactly NF-kB and MVD is correlated.

\section{CONCLUSION}

This study has not confirmed any correlation between NF- $\kappa \mathrm{B}$ and MVD. Nevertheless, positive NF- $\kappa B$ expression and high MVD were found many among these patients. In the future, further research needs to be done to get a better assessment on nuclear proliferation rates and tumor-related angiogenesis in NPC.

\section{REFERENCES}

[1] Zhu DD, Zhang J, Deng W, Yip YL, Lung HL, Tsang CM, et al. Significance of NF-KB activation in immortalization of nasopharyngeal epithelial cells. International journal of cancer. 2016;138(5):1175-85.

[2] Tsao SW, Tsang CM, To KF, Lo KW. The role of Epstein-Barr virus in epithelial malignancies. The Journal of pathology. 2015;235(2):323-33.

[3] Serasanambati M, Chilakapati SR. Function of nuclear factor kappa $\mathrm{B}(\mathrm{NF}-\mathrm{kB})$ in human diseases-a review. South Ind J Biol Sci. 2016;2:368-87.

[4] Shih VF-S, Tsui R, Caldwell A, Hoffmann A. A single NFkB system for both canonical and non-canonical signaling. Cell research. 2011;21(1):86-102.

[5] Staudt LM. Oncogenic activation of NF- $\kappa$ B. Cold Spring Harbor perspectives in biology. 2010;2(6):a000109.

[6] Ghosh S, Hayden MS. Celebrating 25 years of NF- $\kappa \mathrm{B}$ research. Immunological reviews. 2012;246(1):5-13

[7] Bauer AJ, Martin KA. Coordinating regulation of gene expression in cardiovascular disease: interactions between chromatin modifiers and transcription factors. Frontiers in cardiovascular medicine. 2017;4:19.

[8] Białas M, Dyduch G, Dudała J, Bereza-Buziak M, HubalewskaDydejczyk A, Budzyński A, et al. Study of microvessel density and the expression of vascular endothelial growth factors in adrenal gland pheochromocytomas. International journal of endocrinology. 2014;2014.

[9] De Donato M, Fanelli M, Mariani M, Raspaglio G, Pandya D, He S, et al. Nek6 and Hif-1 $\alpha$ cooperate with the cytoskeletal gateway of drug resistance to drive outcome in serous ovarian cancer. American journal of cancer research. 2015;5(6):1862.

[10] Adham M, Kurniawan AN, Muhtadi AI, Roezin A, Hermani B, Gondhowiardjo $\mathrm{S}$, et al. Nasopharyngeal carcinoma in Indonesia: epidemiology, incidence, signs, and symptoms at presentation. Chinese journal of cancer. 2012;31(4):185.

[11] Wolff HA, Rödel RM, Gunawan B, Overbeck T, Herrmann MK, Hennies S, et al. Nasopharyngeal carcinoma in adults: treatment results after long-term follow-up with special reference to adjuvant interferon-beta in undifferentiated carcinomas. Journal of cancer research and clinical oncology. 2010;136(1):89-97.

[12] Rahman S, Subroto H, Budiman B, Asri A, Bachtiar H. Expression of epidermal growth factor receptor in advance stage nonkeratinizing nasopharyngeal carcinoma in West Sumatra, Indonesia. Archive of Oncology. 2018;24(2):20-3.

[13] Li Z, Zong Y-s. Review of the histological classification of nasopharyngeal carcinoma. Journal of Nasopharyngeal Carcinoma. 2014;1(15).

[14] Rofi'il A, Fatchiyah F, Rahayu P , Muhyi R, Sumitro SB. Reactive oxygen species, NF- $\square$ B, and p53 levels in tissue of undifferentiated nasopharyngeal carcinoma. Oxidants and Antioxidants in Medical Science. 2013; 2(2):143-147.

[15] Valentine R, Dawson CW, Hu C, et al. Epstein-Barr virus-encoded EBNA1 inhibits the canonical NF-kappaB pathway in carcinoma cells by inhibiting IKK phosphorylation. Molecular Cancer 2010; 9: 1.

[16] Chung GT, Lou WP, Chow C, et al. Constitutive activation of distinct NF- $\kappa \mathrm{B}$ signals in EBV-associated nasopharyngeal carcinoma. Journal of Pathology. 2013; 231: 311-322.

[17] Chang K-C, Chang Y, Wang LH-C, Tsai H-W, Huang W, Su I-J. Pathogenesis of virus-associated human cancers: Epstein-Barr virus and hepatitis B virus as two examples. Journal of the Formosan Medical Association. 2014;113(9):581-90.

[18] Yan M, Xu Q, Zhang P, Zhou X-j, Zhang Z-y, Chen W-t. Correlation of NF- $\mathrm{KB}$ signal pathway with tumor metastasis of human head and neck squamous cell carcinoma. BMC cancer. 2010;10(1):437.

[19] Zhang J, Peng B, Chen X. Expressions of nuclear factor $\kappa B$, inducible nitric oxide synthase, and vascular endothelial growth factor in adenoid cystic carcinoma of salivary glands: correlations with the 
angiogenesis and clinical outcome. Clinical Cancer Research. 2005;11(20):7334-43

[20] Pires FR, Da Silva PJS, Natal RF, Alves FA, Pinto CAL, Rumayor A, et al. Clinicopathologic features, microvessel density, and immunohistochemical expression of ICAM-1 and VEGF in 15 cases of secondary syphilis with oral manifestations. Oral surgery, oral medicine, oral pathology and oral radiology. 2016;121(3):274-81.

[21] Zhuo X, Chang A, Huang C, Yang L, Xiang Z, Zhou Y. Expression and clinical significance of microvessel density and its association with TWIST in nasopharyngeal carcinoma. International journal of clinical and experimental medicine. 2015;8(1):1265.

[22] Szafarowski T, Sierdzinski J, Szczepanski MJ, et al. Microvessel density in head and neck squamous cell carcinoma. European Archives of Oto-Rhino-Laryngology. 2018; 275:1845-1851.

[23] Taweevisit M, Keelawat S, Thoner PS. Correlation of microvascular density and proliferation index in undifferentiated nasopharyngeal carcinoma. Asian Biomed 2010; 4(2):315-21.

[24] Li W, Tan D, Zenali MJ, Brown RE. Constitutive activation of nuclear factor-kappa B (NF- $\kappa \mathrm{B})$. Signaling pathway in fibrolamellar hepatocellular carcinoma. Int J Clin Exp Pathol 2010;3(3):238-243.

[25] Khater DS, Kasem RF, Morsy, RA. Immunohistochemical Analysis of Nf- $\kappa \mathrm{B}$ Expression and its Relation to Apoptosis and Proliferation in Different Odontogenic Tumors. International Journal of Cancer Research. 2017; 13(2): 76-83.

[26] Muina, Agus S, Rahman S. Ekspresi Vascular Endothelial Growth Factor dan Peningkatan Microvessel Density pada Karsinoma Nasofaring Tidak Berkeratin. Majalah Patologi.208; 27(3): 30-35.

[27] Hasibuan NR, Farhat, Haryuna TSH, Yudhistira A. Korelasi positif ekspresi cyclooxygenase-2 dengan microvessel density pada karsinoma nasofaring. ORLI: 2014; 44(1). 